\title{
PENELITIAN PENGOLAHAN PRODUK CAMILAN IKAN KERING DARI IKAN SELAR KUNING (Selaroides leptolepis)
}

\author{
Hari Eko Irianto", Sugiyono") dan Ninoek Indriati*
}

\begin{abstract}
ABSTRAK
Penelitian pengolahan produk camilan ikan kering telah dilakukan dengan menggunakan bahan mentah ikan selar kuning. Penelitian dilaksanakan dua tahap, yaitu penelitian tahap pertama dan penelitian tahap ke dua. Pada penelitian tahap pertama diteliti pengaruh konsentrasi garam larutan perendam $(3,5,10$, dan $15 \%)$ dan lama waktu perendaman $(0,5,10$, dan 15 menit). Hasil penelitian tersebut menunjukkan bahwa larutan yang digunakan sebaiknya pada konsentrasi garam 3\% dan lama perendaman 15 menit). Pada penelitian tahap ke dua diselidiki pengaruh teknik pengeringan (matahari dan pengering mekanis) dan lama pengeringan sebelum pengepresan $(0,3,6,9$, dan 12 jam). Hasil penelitian tahap ke dua menunjukkan bahwa pengeringan yang disarankan adalah menggunakan pengering mekanis dan pengepresan sebaiknya tidak diterapkan. Komposisi proksimat produk yang memiliki penerimaan tertinggi adalah kadar air 15,89\%; kadar abu 8,72\%; kadar protein $63,47 \%$; dan kadar lemak 5,37\%.
\end{abstract}

ABSTRACT: Study on the processing of dried fish snack from yellow stripe travelly (Selaroides leptolepis). By: Hari Eko Irianto, Sugiyono, and Ninoek Indriati.

Study on the processing of dried fish snack has been carried out by using yellowstripes trevally as raw material. The study was conducted in two steps. The first experiment investigated the effects of salt concentration in brine solution (3, 5, 10, and 15\%) and soaking period in the brine $(0,5$, 10. and 15 minutes). Results of that study indicated that the suggested salt concentration and soaking period were $3 \%$ and 15 minutes respectively. The second experiment studied the effects of drying methods (sun drying and mechanical drying) and drying period prior to pressing. Results showed that mechanical drying and no-pressing treatment were recommended to process dried fish snack. Proximate composition of the product having the highest acceptability score was $15.89 \%$ moisture; 8,72\% ash; 63,47\% protein; and 5,37\% fat.

KEYWORDS: dried fish snack, yellow stripe travelly

\section{PENDAHULUAN}

Ikan selar kuning merupakan ikan musiman di mana pada suatu saat tertentu produksinya melimpah. Pada kondisi tersebut diperlukan caracara pengolahan dan pengawetan yang sesuai, sehingga kelebihan produksinya dapat dimanfaatkan secara optimal. Total produksi ikan selar kuning pada tahun 1996 adalah 116.193 ton (Direktorat Jenderal Perikanan, 1998). Selama ini, ikan selar kuning selain dipasarkan dalam bentuk segar, juga dipasarkan dalam bentuk olahan ikan asin kering dan dendeng. Untuk mendapatkan pasar yang lebih luas perlu dikembangkan produk-produk olahan yang lain, sehingga dapat menjangkau konsumen dari berbagai kalangan, baik ditinjau dari segi ekonomi maupun selera

Di dalam penelitian ini dikembangkan satu produk olahan ikan kering dari ikan selar kuning berupa produk camilan ikan kering. Produk yang dikembangkan merupakan produk ikan belah butterfly yang telah dihilangkan tulangnya, sehingga memudahkan di dalam konsumsi dan aman bagi anak-anak. Pembuatan camilan ikan kering memiliki prospek yang cukup bagus, karena kemudahan dalam pemasarannya. Nilai tambah yang diperoleh dengan mengolahnya menjadi camilan diperkirakan lebih tinggi dibandingkan jika diolah menjadi ikan asin. Selain itu pembuatan camilan ikan kering sangat sesuai dilakukan dalam bentuk industri rumah tangga.

Produk camilan ikan kering yang dihasilkan dalam penelitian ini tergolong dalam tingkat keasinan ringan (lightly salted fish). Salah satu kendala yang membatasi konsumsi ikan asin adalah rasanya yang terlalu asin akibat kadar garam yang terlalu tinggi. Selain itu produk yang kadar garamnya terlalu tinggi sering dihubungkan sebagai penyebab penyakit tekanan darah tinggi. Produk camilan ikan kering berkadar garam rendah yang dihasilkan di dalam penelitian ini diharapkan dapat mengatasi hambatan dalam mengkonsumsi produk ikan asin. Produk sejenis telah terdapat di pasaran, tetapi pada umumnya dalam bentuk tawar, sehingga rasanya kurang menarik. 


\section{BAHAN DAN METODE}

\section{Bahan}

Di dalam penelitian ini digunakan ikan selar kuning (Selaroides leptolepis) sebagai bahan mentahnya. Ikan tersebut dibeli dari Tempat Pendaratan Ikan Belanakan, Indramayu. Ikan dalam keadaan segar ditransportasikan dengan di-es dalam cool box (perbandingan es dan ikan 1:1). Ukuran ikan yang digunakan adalah panjang total $11,5-13,0 \mathrm{~cm}$, lebar $3,5-4,0 \mathrm{~cm}$, tebal $1,3-1,5 \mathrm{~cm}$ dan bobot 20-30 g/ekor. Komposisi proksimat ikan tersebut adalah $75,95 \%$ air; $4,67 \%$ abu; $17,35 \%$ protein; dan $2,29 \%$ lemak.

\section{Metode}

Untuk mendapatkan produk dengan penerimaan organoleptik yang baik, penelitian dilaksanakan dalam dua tahap, yaitu penelitian tahap pertama dan penelitian tahap ke dua.

\section{Percobaan tahap pertama}

Pada penelitian tahap pertama ditentukan kondisi optimum perlakuan konsentrasi larutan garam perendam dan lama perendaman untuk mendapatkan produk yang paling diterima oleh panelis. Penelitian dilaksanakan menggunakan rancangan acak lengkap faktorial $4 \times 4$ dengan dua kali ulangan. Variasi untuk masing-masing perlakuan adalah sebagai berikut:

Konsentrasi larutan garam : 3, 5, 10, dan $15 \%$ Lama perendaman $0,5,10$, dan 15 menit

Setelah perendaman dalam larutan garam, ikan dikeringkan dengan penjemuran selama 12 jam (dua hari). Produk yang diperoleh dari perlakuan-perlakuan tersebut diamati secara organoleptis untuk mengetahui tingkat penerimaan panelis terhadap parameter-parameter penampakan, warna, kecerahan, bau, rasa, kerenyahan, dan penerimaan umum melalui uji hedonik skala 1-9 (1 = amat sangat tidak suka; 9 = amat sangat suka). Untuk pengamatan rasa dan kerenyahan, produk digoreng terlebih dahulu. Selain itu terhadap produk tersebut juga ditentukan kadar air dan kadar garamnya (AOAC, 1984). Produk dipersiapkan dengan mengikuti alur proses pada Gambar 1.

\section{Percobaan tahap ke dua}

Pada penelitian tahap ke dua diselidiki pengaruh dari perlakuan pengepresan terhadap ikan selama proses pengeringan dan perlakuan cara

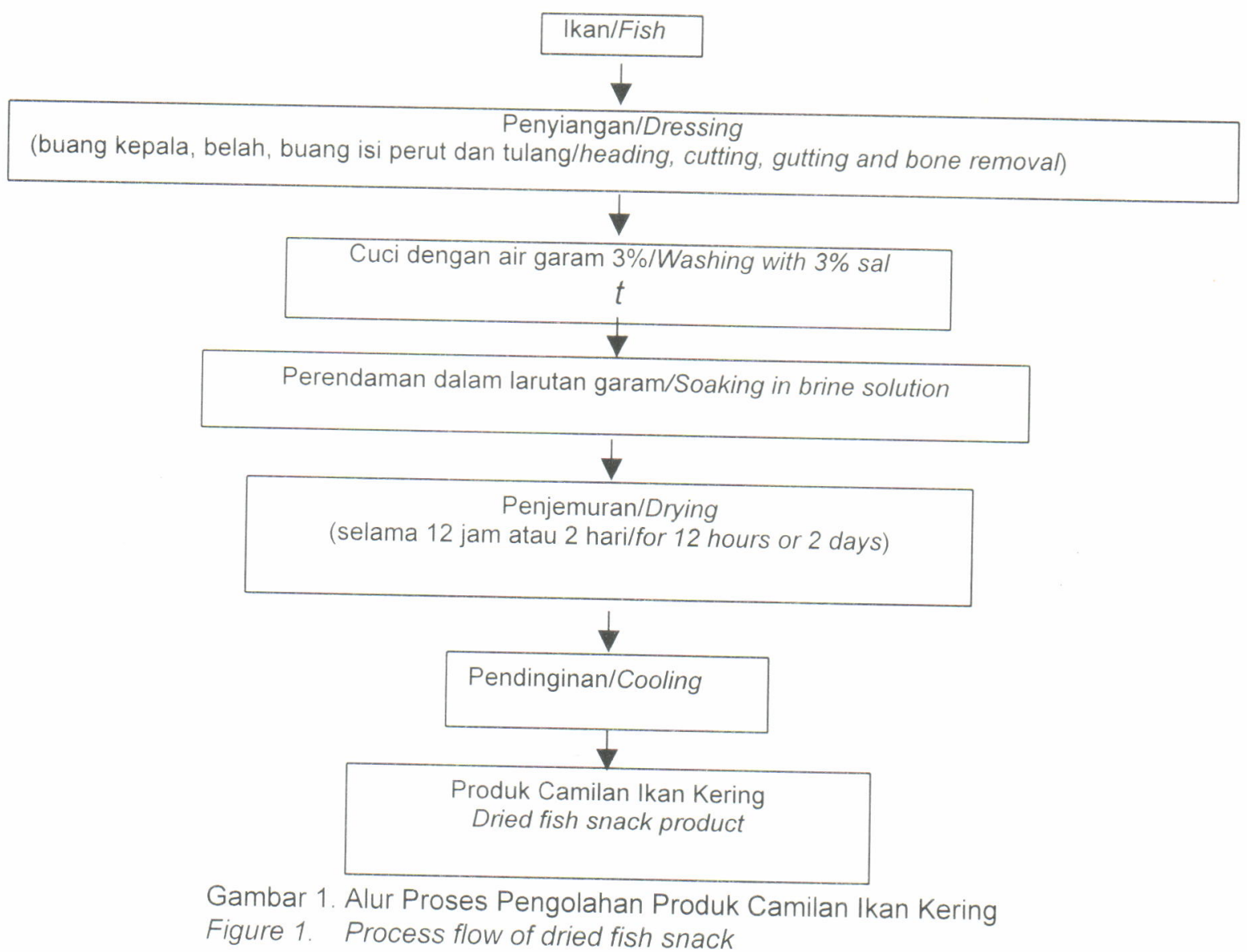


pengeringan. Produk diolah dengan perendaman dalam larutan garam pada konsentrasi dan lama perendaman berdasarkan hasil penelitian pada tahap pertama. Rancangan acak lengkap faktorial $2 \times 5$ digunakan di dalam penelitian ini. Penelitian dilaksanakan dengan dua kali ulangan. Variasi dari masing-masing perlakuan adalah sebagai berikut.

- Teknik pengeringan: pengeringan sinar matahari dan pengeringan dengan menggunakan pengering mekanis pada suhu $40-45^{\circ} \mathrm{C}$

- Pengepresan setelah pengeringan: 3,6, 9, dan 12 jam serta kontrol tanpa pengepresan.

Pengepresan dimaksudkan untuk menghasilkan produk yang lebih tipis dan lebih renyah dibandingkan dengan produk yang tanpa di-pres. Pengepresan dilakukan dengan menggunakan bagian untuk menipiskan adonan pada alat pembuat mie merk Super Mesin Mie Model KL 94, buatan Kebayoran Teknik, Jakarta dengan skala 3. Pengering mekanis yang digunakan adalah pengering sistem terowongan (tunnel) yang terdiri atas tiga bagian ruang pengering dengan ukuran panjang masing-masing sisi untuk setiap ruang pengering $1 \mathrm{~m}$. Untuk pengeringannya, produk terlebih dahulu diatur di atas trays dan kemudian ditempatkan secara acak di dalam ruang pengering. Suhu pengeringan diatur sekitar $40-45^{\circ} \mathrm{C}$ dengan cara mengatur besar api. Sedangkan untuk camilan ikan yang dikeringkan dengan sinar matahari, produk diletakkan pada trays dan kemudian ditempatkan pada para-para penjemuran. Pada saat penjemuran, produk ditutup dengan kasa plastik untuk mencegah dihinggapi lalat.

Produk yang diperoleh diamati secara organoleptik seperti pada penelitian tahap pertama dan produk yang memiliki penerimaan paling baik dianalisis komposisi proksimat (AOAC, 1984) dan profil asam aminonya dengan menggunakan HPLC merk Waters model 510 yang dilengkapi dengan Fluoresence Detector dan Pico Tag 420 column serta menggunakan Hitachi 15-20 spectrophotometer. Metode analisis penentuan profil asam amino mengikuti metode yang diterangkan oleh Anonymous (1987). Penentuan profil asam amino dimaksudkan untuk mengetahui asam amino yang berperan di dalam memberikan rasa dari produk.

\section{HASIL DAN BAHASAN}

\section{Pengaruh Konsentrasi Garam dan Lama Perendaman Terhadap Camilan Ikan}

\section{Pengaruh terhadap penerimaan organoleptik}

Hasil pengamatan organoleptik camilan ikan yang dihasilkan pada penelitian tahap pertama dapat dilihat pada Tabel 1
Penerimaan panelis terhadap penampakan, warna, kecerahan, dan bau camilan ikan sangat nyata dipengaruhi oleh konsentrasi garam yang digunakan dalam larutan perendaman. Perlakuan perendaman dalam larutan garam dapat meningkatkan penerimaan penampakan, warna, kecerahan, kerenyahan, dan bau dari produk yang ditunjukkan dengan lebih tingginya nilai penerimaan parameter-parameter tersebut dibandingkan dengan produk yang tidak mendapat perlakuan perendaman dalam larutan garam. Uji ganda Duncan menunjukkan bahwa penampakan, warna, kecerahan, dan bau produk yang diolah dengan direndam dalam larutan garam $5 \%$ dan $10 \%$ secara nyata lebih disukai dibandingkan dengan yang direndam dalam larutan garam 3\% dan $10 \%$. Salah satu faktor yang berperan terhadap penampakan, warna, kecerahan, dan bau produk dalam hubungan dengan penggunaan garam adalah oksidasi. Hasil penelitian Nambuary (1980) menunjukkan bahwa garam mempunyai kemampuan di dalam menghambat reaksi oksidasi lemak. Kadar garam tertinggi yang diamati di dalam penelitian tersebut adalah $8 \%$. Sebaliknya Zaitsev et al. (1969) menyatakan bahwa garam dapat mempercepat proses oksidasi lemak, terutama bila diberikan pada permukaan kontak yang luas. Kedua informasi tersebut menunjukkan bahwa garam mempunyai kemampuan di dalam mengendalikan oksidasi. Dengan demikian beradasarkan hasil penelitian ini, penggunaan larutan dengan konsentrasi garam sedang (5\%-10\%) dapat menghasilkan produk camilan ikan kering dengan penampakan, warna dan bau yang lebih disukai dibandingkan dengan larutan perendam berkonsentrasi garam rendah (3\%) dan tinggi (15\%). Nilai kesukaan terhadap penampakan, warna, kecerahan, dan bau tertinggi ditunjukkan oleh produk yang diolah dengan perendaman dalam larutan garam 10 persen selama 10 menit.

Analisis statistik menunjukkan bahwa nilai kesukaan panelis terhadap kerenyahan produk dipengaruhi oleh konsentrasi garam larutan perendam. Dari uji ganda Duncan diperoleh bahwa nilai kesukaan kerenyahan produk tertinggi adalah produk yang direndam dalam larutan garam 3\% selama 10 dan 15 menit. Secara keseluruhan berdasarkan konsentrasi garam larutan perendam. terdapat suatu kecenderungan bahwa kerenyahan produk yang paling diterima oleh panelis adalah yang diproses dengan perendaman dalam larutan garam $3 \%$, kemudian disusul berturut-turut oleh produk yang direndam dalam larutan garam $5 \%, 10 \%$, dan $15 \%$. Pada proses penggaraman terjadi penghilangan sebagian air dari jaringan daging ikan dan digantikan secara parsial oleh garam. Pada saat air keluar dari 


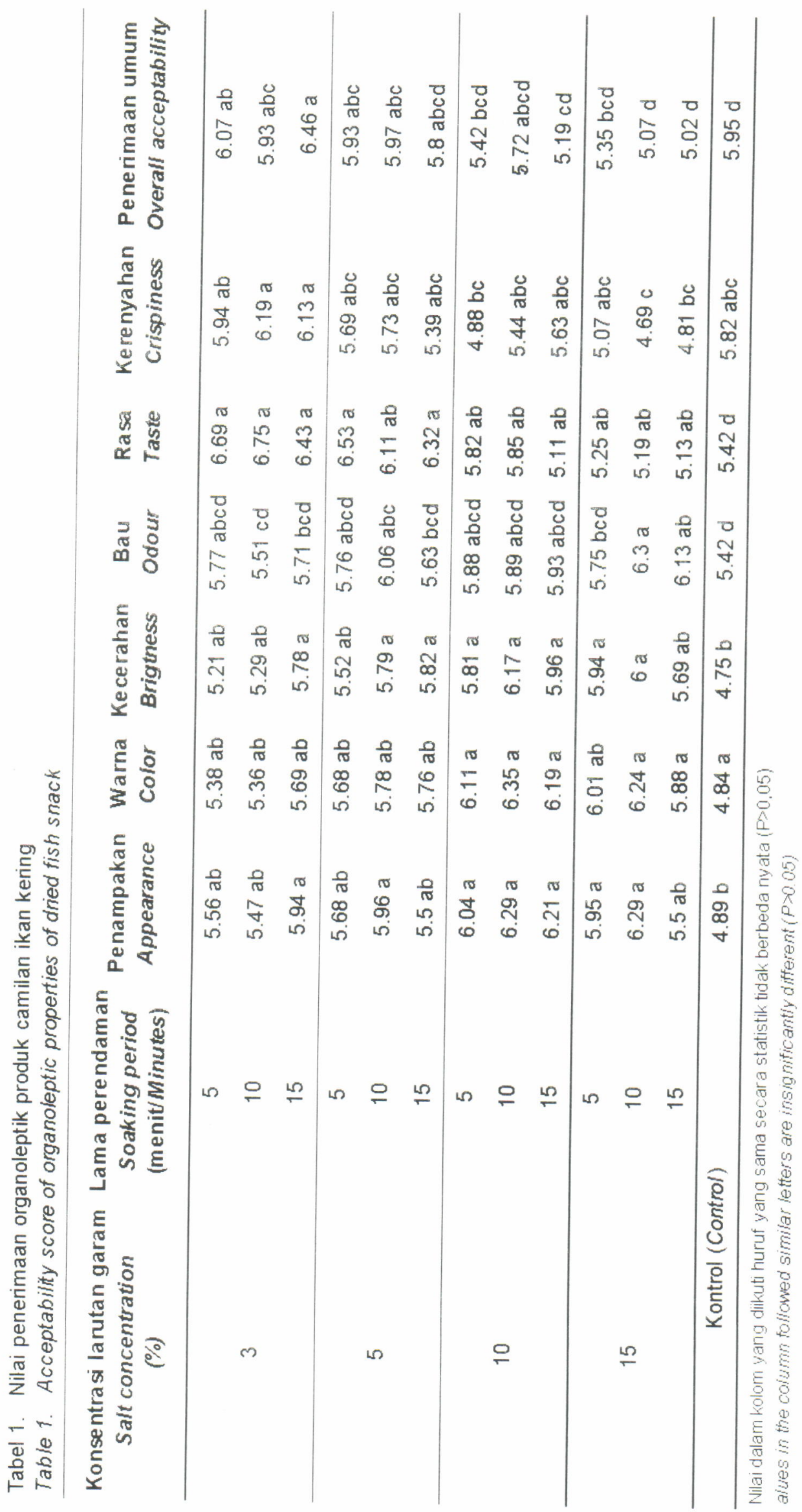


Tabel 2. Kadar air dan kadar garam camilan ikan kering

Table 2. Moisture and salt contents of dried fish snack

\begin{tabular}{cccc}
\hline $\begin{array}{c}\text { Konsentrasi larutan garam } \\
\text { Salt concentration } \\
(\%)\end{array}$ & $\begin{array}{c}\text { Lama pe rendaman } \\
\text { Soaking period } \\
\text { (menit/Minutes) }\end{array}$ & $\begin{array}{c}\text { Kadar Air } \\
\text { Moisture content } \\
(\%)\end{array}$ & $\begin{array}{c}\text { Kadar garam (Salt content) } \\
\text { (\% bobot kering } \\
\text { IDry weight bases) }\end{array}$ \\
\hline \multirow{2}{*}{3} & 5 & 11.77 & $1.54 \mathrm{f}$ \\
\multirow{2}{*}{5} & 10 & 12.72 & $1.66 \mathrm{f}$ \\
& 15 & 13.11 & $2.39 \mathrm{ef}$ \\
\hline \multirow{2}{*}{10} & 5 & 11.96 & $1.63 \mathrm{f}$ \\
& 10 & 13.45 & $2.61 \mathrm{ef}$ \\
& 15 & 13.69 & $3.63 \mathrm{de}$ \\
\hline \multirow{2}{*}{15} & 5 & 16.77 & $4.47 \mathrm{~d}$ \\
& 10 & 15.57 & $7.11 \mathrm{~b}$ \\
\hline & 15 & 14.95 & $6.02 \mathrm{bc}$ \\
& 10 & 16.72 & $9.64 \mathrm{~b}$ \\
\hline & 15 & 16.17 & $1.64 \mathrm{a}$ \\
\hline
\end{tabular}

Nilai dalam kolom yang diikuti huruf yang sama secara statistik tidak berbeda nyata ( $P>0.05)$

Values in the columns followed by similar letters are insignificantly different $(P>0.05)$

jaringan, secara bersamaan garam masuk. Berdasarkan hasil penelitian ini dapat diduga bahwa penetrasi garam ke dalam jaringan daging ikan pada larutan perendam dengan konsentrasi garam tinggi lebih cepat dibandingkan dengan yang konsentrasi rendah dan dalam rentang waktu perendaman yang sama menunjukkan kadar garam yang lebih tinggi (Tabel 2). Menurut Noguchi (1972), penetrasi garam dipengaruhi oleh konsentrasi dan kemurnian garam, ukuran ikan, kandungan lemak daging, dan suhu sekitarnya. Garam bersifat higroskopis yang cenderung mengikat air yang ada di udara sekitarnya (Clucas \& Ward, 1996), sehingga menyebabkan produk yang direndam pada larutan berkonsentrasi garam lebih tinggi cenderung mempunyai kandungan air yang lebih tinggi (Tabel 2). Hal ini berpengaruh terhadap kerenyahan produk camilan ikan yang dihasilkan. Produk camilan ikan yang memiliki nilai penerimaan tertinggi adalah yang diproses dengan perendaman dalam larutan garam $3 \%$ selama 10 menit.

Penerimaan panelis terhadap rasa produk camilan ikan secara sangat nyata dipengaruhi oleh konsentrasi garam dalam larutan perendam, lama perendaman, dan interaksi antara kedua perlakuan. Produk yang mempunyai nilai kesukaan rasa paling tinggi adalah yang diolah dengan perendaman dalam larutan garam 3\% selama 10 menit. Hasil tersebut sesuai dengan pengalaman Noguchi (1972) bahwa larutan garam yang dapat memberikan rasa paling sedap pada pengolahan produk ikan asin adalah pada konsentrasi $3-5 \%$

Nilai kesukaan rasa cenderung menurun dengan meningkatnya konsentrasi garam dalam larutan perendam. Walaupun demikian perlakuan perendaman dalam larutan garam dapat meningkatkan nilai kesukaan rasa camilan ikan. Hal ini ditunjukkan oleh kenyataan bahwa nilai kesukaan rasa produk yang diolah dengan merendam dalam larutan garam lebih tinggi dibandingkan dengan yang tidak direndam dalam larutan garam. Garam memiliki sifat sebagai penegas rasa suatu produk pangan.

Analisis sidik ragam menunjukkan bahwa nilai penerimaan produk secara keseluruhan dipengaruhi sangat nyata oleh konsentrasi garam larutan perendam serta dipengaruhi secara nyata oleh lama perendaman dan interaksi keduanya. Produk camilan ikan yang menunjukkan penerimaan paling tinggi adalah yang diolah dengan perendaman dalam larutan garam 3\% selama 15 menit. Oleh karena itu kondisi penggaraman tersebut diterapkan pada penelitian tahap ke dua.

\section{Pengaruh terhadap kadar air dan kadar garam}

Perlakuan konsentrasi garam pada larutan perendam berpengaruh nyata terhadap kadar air produk camilan ikan yang dihasilkan. Kadar air tertinggi ditunjukkan oleh camilan ikan yang diolah dengan perendaman dalam larutan garam $15 \%$, dan kemudian 
diikuti berturut-turut oleh produk yang dalam pengolahannya direndam dalam larutan garam 10, 5 , dan 3\%. Kecenderungan serupa juga ditunjukkan oleh kadar garam produk. Dengan demikian apabila dibuat hubungan antara kadar air dan kadar garam produk akan diperoleh suatu kecenderungan, yaitu bahwa semakin tinggi kadar air produk berarti semakin tinggi kadar garamnya. Sifat higroskopis garam yang cenderung mengikat air seperti yang telah disinggung sebelumnya tampaknya sangat berpengaruh terhadap kadar air produk camilan ikan yang dihasilkan.

Kadar garam produk camilan ikan sangat nyata dipengaruhi oleh konsentrasi garam larutan perendam dan lama perendaman. Interaksi antara kedua perlakuan tersebut berpengaruh nyata terhadap kadar garam produk. Semakin tinggi konsentrasi garam larutan perendam dan semakin lama perendaman menghasilkan produk dengan kadar garam yang semakin tinggi pula. Kedua perlakuan tersebut merupakan faktor penting yang menentukan kadar garam dari produk hasil penggaraman (Poernomo, 1986a), termasuk camilan ikan ini. Indikasi serupa ditunjukkan oleh Hutuely et al. (1991) pada proses penggaraman ikan layang. Kadar garam tertinggi $(9,63$ persen b.k.) ditunjukkan oleh camilan ikan yang diolah dengan perendaman dalam larutan garam 15\% selama 15 menit. Sedangkan produk yang menunjukkan penerimaan organoleptik paling disukai memiliki kadar garam 2,39 persen (b.k.).

\section{Pengaruh Cara Pengeringan dan Perlakuan Pengepresan}

\section{Pengaruh terhadap lama pengeringan}

Perlakuan pengepresan berpengaruh terhadap pola penurunan bobot ikan selama pengeringan matahari (Lampiran 1). Pada produk yang mendapat perlakuan pengepresan setelah tiga jam pengeringan, proses pengeringan dapat dihentikan pada jam ke-6. Sedangkan untuk produk yang dipres setelah 6, 9, dan 12 jam pengeringan, proses pengeringan dapat dihentikan pada jam ke-12 pengeringan

Pada pengeringan dengan pengering mekanis, diperoleh kecenderungan yang berbeda terhadap penurunan bobot ikan selama pengeringan (Lampiran 2). Untuk semua perlakuan pengepresan menunjukkan bahwa proses pengeringan dianggap cukup pada jam ke-9.

\section{Pengaruh terhadap penerimaan organoleptik}

Nilai penerimaan panelis terhadap penampakan produk camilan ikan sangat nyata dipengaruhi oleh metode pengeringan, perlakuan pengepresan, dan interaksi kedua perlakuan. Penampakan produk yang dikeringkan dengan pengering mekanis lebih disukai dibandingkan dengan yang dikeringkan melalui pengeringan sinar matahari. Nilai kesukaan penampakan produk yang dipres setelah tiga jam pengeringan lebih rendah dibandingkan dengan produk yang lain. Ikan yang dikeringkan selama tiga jam teksturnya masih lembek (belum kompak) sehingga ketika dipres dagingnya hancur, yang akhirnya mengakibatkan penampakan bagian permukaan produk kasar dan tidak disukai oleh panelis. Sedangkan pengeringan 6, 9, dan 12 jam menghasilkan ikan dengan tekstur yang lebih kompak, sehingga ketika dilakukan pengepresan daging ikan tidak hancur dan menyebabkan perubahan bentuk menjadi lebih tipis dengan kondisi daging ikan tetap menyatu, walaupun permukaannya sedikit lebih kasar dibandingkan dengan yang tanpa pengepresan. Camilan ikan yang menunjukkan penampakan paling disukai oleh panelis adalah yang dikeringkan dengan pengering mekanis dan tanpa pengepresan

Perlakuan metode pengeringan dan perlakuan pengepresan berpengaruh sangat nyata terhadap nilai kesukaan warna oleh panelis. Pengering mekanis menghasilkan produk dengan warna yang lebih disukai oleh panelis. Warna produk yang dihasilkan dengan pengeringan matahari lebih coklat dibandingkan yang dikeringkan dengan pengering mekanis. Warna coklat diduga terjadi akibat reaksi pencoklatan non-enzimatis antara protein, peptidapeptida dan asam amino bebas dengan hasil dekomposisi lemak (Khayat \& Schwall, 1983). Pada pengeringan mekanis produk dikeringkan dalam ruangan gelap dengan suhu $40-45^{\circ} \mathrm{C}$, sedangkan pada pengeringan matahari produk dikeringkan pada tempat terbuka dan terkena sinar matahari dengan suhu tertinggi $33^{\circ} \mathrm{C}$. Tampaknya adanya sinar matahari adalah yang paling berperan di dalam proses oksidasi lemak, sehingga menghasilkan produk hasil dekomposisi lemak yang lebih banyak dan hasil reaksinya dengan protein, peptida dan asam amino yang menyebabkan warna produk yang lebih coklat dibandingkan dengan yang dikeringkan sinar matahari. Warna produk yang diperoleh dari pengepresan setelah tiga jam pengeringan sangat nyata kurang disukai dibandingkan dengan produk yang pengepresannya dilakukan setelah 6,9 , dan 12 jam pengeringan serta tanpa pengepresan. Warna produk yang paling disukai adalah yang tanpa dipres dan dikeringkan menggunakan pengering mekanis.

Nilai kesukaan terhadap kecerahan produk sangat nyata dipengaruhi oleh lama pengeringan sebelum dipres. Berdasarkan uji ganda Duncan, nilai kesukaan kecerahan untuk produk yang diolah tanpa 
Tabel 3. Nilai penerimaan produk camilan ikan kering

Table 3. Acceptability score of dried fish snack

\begin{tabular}{|c|c|c|c|c|c|c|c|c|}
\hline $\begin{array}{c}\text { Pengeringan } \\
\text { Drying }\end{array}$ & $\begin{array}{l}\text { Lama pengeringan } \\
\text { sebelum } \\
\text { penge presan (jam) } \\
\text { Drying period before } \\
\text { pressing } \\
\text { Hours) }\end{array}$ & $\begin{array}{c}\text { Penampakan } \\
\text { Appearance }\end{array}$ & $\begin{array}{l}\text { Warna } \\
\text { Color }\end{array}$ & $\begin{array}{c}\text { Kecerahan } \\
\text { Brigtness }\end{array}$ & $\begin{array}{c}\text { Bau } \\
\text { Otdour }\end{array}$ & $\begin{array}{l}\text { Rasa } \\
\text { Taste }\end{array}$ & $\begin{array}{c}\text { Keranyahan } \\
\text { Crispiness }\end{array}$ & $\begin{array}{c}\text { Penerimaan } \\
\text { umum } \\
\text { Overall } \\
\text { acce ptability }\end{array}$ \\
\hline & $\begin{array}{c}\text { Tanpa pengepresan } \\
\text { Without pressing }\end{array}$ & $7.02 \mathrm{bc}$ & $6.94 \mathrm{ab}$ & $6.93 a b$ & $6.37 \mathrm{bc}$ & $6.93 \mathrm{bc}$ & $6.32 \mathrm{bc}$ & $6.57 \mathrm{bc}$ \\
\hline $\begin{array}{l}\text { Matahari } \\
\text { Sun drying }\end{array}$ & $\begin{array}{c}3.00 \\
6.00 \\
9.00 \\
12.00\end{array}$ & $\begin{array}{l}4.34 \mathrm{~g} \\
6.21 \mathrm{ef} \\
6.83 \mathrm{~cd} \\
6.9 \mathrm{bcd}\end{array}$ & $\begin{array}{l}5.2 c \\
6.46 b \\
6.83 b \\
6.8 b\end{array}$ & $\begin{array}{l}4.99 d \\
6.8 a b \\
6.83 a b \\
6.6 a b c\end{array}$ & $\begin{array}{c}5.75 \mathrm{c} \\
6.13 \mathrm{bc} \\
6.33 \mathrm{abc} \\
6.5 \mathrm{ab}\end{array}$ & $\begin{array}{l}6.2 \mathrm{c} \\
6.46 \mathrm{bc} \\
6.33 \mathrm{bc} \\
6.8 \mathrm{ab}\end{array}$ & $\begin{array}{l}6.02 \mathrm{c} \\
6.46 \mathrm{bc} \\
6.33 \mathrm{bc} \\
6.8 \mathrm{ab}\end{array}$ & $\begin{array}{l}5.2 d \\
6.42 c \\
6.5 b c \\
6.7 b c\end{array}$ \\
\hline $\begin{array}{l}\text { Pengering } \\
\text { mekanis } \\
\text { Mechanical } \\
\text { dryer }\end{array}$ & $\begin{array}{c}\text { Tanpa pengepresan } \\
\text { Without pressing } \\
3.00 \\
6.00 \\
9.00 \\
12.00\end{array}$ & $\begin{array}{c}7.59 \mathrm{a} \\
5.75 \mathrm{f} \\
7.42 \mathrm{ab} \\
6.84 \mathrm{~cd} \\
6.422 \mathrm{de}\end{array}$ & $\begin{array}{c}7.5 a \\
6.34 b \\
7.5 a \\
6.92 a b \\
6.75 b\end{array}$ & $\begin{array}{c}7.33 \mathrm{a} \\
6.0 \mathrm{c} \\
7.25 \mathrm{a} \\
6.67 \mathrm{abc} \\
6.42 \mathrm{bc}\end{array}$ & $\begin{array}{c}6.75 \mathrm{ab} \\
6.5 \mathrm{ab} \\
6.92 \mathrm{a} \\
6.92 \mathrm{a} \\
6.67 \mathrm{ab}\end{array}$ & $\begin{array}{c}7.17 \mathrm{a} \\
6.84 \mathrm{ab} \\
7.0 \mathrm{a} \\
7.09 \mathrm{a} \\
6.75 \mathrm{ab}\end{array}$ & $\begin{array}{c}7.42 \mathrm{a} \\
6.92 \mathrm{ab} \\
7.25 \mathrm{a} \\
6.92 \mathrm{ab} \\
6.92 \mathrm{ab}\end{array}$ & $\begin{array}{c}7.4 a \\
6.5 b c \\
7.3 a \\
7.0 a b \\
6.6 b c\end{array}$ \\
\hline
\end{tabular}

Nilai dalam kolom yang diikuti huruf yang sama secara statistik tidak berbeda nyata $(P>0,05)$

Values in the column follo wed by similar letters are insignificantly different $(P>0.05)$

pengepresan dan dengan pengepresan setelah enam dan sembilan jam pengeringan tidak berbeda nyata. Nilai kesukaan kecerahan produk yang tanpa dipres secara nyata lebih baik dibandingkan yang dipres setelah 12 dan tiga jam pengeringan. Sedangkan kecerahan produk yang paling tidak disukai oleh panelis adalah produk yang dipres setelah tiga jam pengeringan. Permukaan produk yang kasar tampaknya sangat mempengaruhi kecerahan dari produk. Camilan ikan yang kecerahannya paling disukai panelis adalah yang dikeringkan menggunakan pengering mekanis dan tanpa pengepresan.

Penerimaan panelis terhadap kerenyahan produk sangat nyata dipengaruhi oleh metode pengeringan. Pengeringan mekanis dapat menghasilkan camilan ikan dengan kerenyahan yang sangat nyata lebih disukai. Kondisi yang diterapkan pada pengeringan mekanis di dalam penelitian ini tampaknya merupakan kondisi yang tepat untuk memperoleh kerenyahan produk yang disukai. Poernomo (1986b) di dalam penelitiannya mendapatkan bahwa pengeringan ikan pada suhu $45^{\circ} \mathrm{C}$ menghasilkan produk dengan tekstur dan penampakan yang paling baik dibandingkan dengan yang dikeringkan pada suhu $35^{\circ} \mathrm{C}$ dan $55^{\circ} \mathrm{C}$.

Analisis statistik menunjukkan bahwa metode pengeringan sangat berpengaruh terhadap nilai kesukaan bau dan rasa dari camilan ikan. Sedangkan perlakuan lama pengeringan sebelum pengepresan tidak berpengaruh nyata. Pengering mekanis menghasilkan bau dan rasa produk yang sangat nyata lebih disukai dibandingkan dengan pengeringan sinar matahari., Seperti yang telah disinggung sebelumnya, pada pengeringan mekanis reaksi oksidasi diduga dapat lebih ditekan dibandingkan dengan pengeringan sinar matahari Pengering mekanis menggunakan suhu lebih tinggi $\left(40-45^{\circ} \mathrm{C}\right)$ diduga dapat menyebabkan inaktivasi sebagian enzim dan bakteri pembusuk, sehingga proses dekomposisi protein, lemak, dan komponen lainnya yang menghasilkan bau dan rasa yang tidak dikehendaki dapat ditekan. Camilan ikan yang bau dan rasanya paling disukai masing-masing adalah yang diolah menggunakan pengering mekanis dengan dipres setelah enam jam pengeringan dan tanpa dipres

Nilai penerimaan produk camilan ikan secara keseluruhan dipengaruhi oleh metode pengeringan, lama pengeringan sebelum pengepresan dan interaksi kedua perlakuan. Seperti hasil pengamatan organoleptik untuk penampakan, warna, bau, rasa, dan kerenyahan, ternyata pengering mekanis juga menghasilkan nilai penerimaan produk secara keseluruhan yang lebih tinggi dibandingkan dengan pengeringan sinar matahari. Hasil yang sama diperoleh pada penelitian Priono et al. (1984) bahwa mutu organoleptik ikan asin yang dikeringkan dengan pengering mekanis lebih baik dibandingkan dengan yang dikeringkan menggunakan pengering surya dan para-para (cara pengeringan sinar matahari yang biasa dilakukan masyarakat). Pengepresan yang dilakukan setelah 3 jam pengeringan menghasilkan produk yang secara keseluruhan paling tidak disukai. 
Tabel 4. Komposisi proksimat dan profil asam amino camilan ikan kering

Table 4. Proximate composistion and amino acid profiles of dried fish snack

\begin{tabular}{lc} 
Kadar air (moisture content (\%)) & 15.89 \\
Kadar abu (Ash content (\% b.b.)) & 8.72 \\
Kadar protein (protein content (\% b.b.)) & 63.47 \\
Kadar lemak ( fat content (\% b. b.)) & 5.37 \\
Asam amino (amino acids ( $\mu g / g$ protein) ) : & \\
Aspartat (aspartic) & 7.80 \\
Glutamat (glutamic) & 140.65 \\
Serin (serine) & 22.30 \\
Glisin (glycine & 28.40 \\
Histidin (histidine) & 46.59 \\
Arginin (arginine) & 15.82 \\
Treonin (threonine) & 12.61 \\
Alanin (alanine) & 7.52 \\
Prolin (proline) & 12.30 \\
Tirosin (tyrosine) & 2.00 \\
Valin (valine) & 3.01 \\
Metionin (methionine) & 5.09 \\
Sistein (cysteine) & 10.24 \\
Isoleusin (isoleucine) & 1.53 \\
Leusin (leucine) & 1.73 \\
Fenilalanin (phenilalanine) & 2.94 \\
Lisin (lycine) & 155.86 \\
\hline
\end{tabular}

Sedangkan camilan ikan yang memiliki nilai penerimaan keseluruhan tertinggi adalah yang diolah dengan pengering mekanis dan tanpa pengepresan. Dengan demikian pengering mekanis dapat digunakan sebagai alternatif untuk pengeringan sebagai pengganti penjemuran, terutama pada saat musim hujan dengan menghasilkan produk yang lebih baik mutu organoleptiknya.

\section{Komposisi proksimat dan profil amino}

Analisis proksimat dan profil asam amino dilakukan terhadap sampel yang memiliki penerimaan terbaik, yaitu produk yang dikeringkan dengan pengering mekanis dan tanpa perlakuan pengepresan. Hasil analisis tersebut dapat dilihat pada Tabel 4.

Berdasarkan hasil analisis profil asam amino, ternyata asam amino yang dominan pada produk camilan ikan selar kuning adalah asam glutamat dan lisin. Asam glutamat adalah asam amino yang sangat berperan di dalam memberikan rasa sedap pada daging ikan, di samping IMP (Inosine Mono Phosphate) (Shimizu, 1997). Sedangkan asam amino lisin adalah asam amino yang umumnya bertindak sebagai asam amino pembatas pada protein nabati dan ternyata produk yang dikembangkan dalam penelitian ini dapat dipakai sebagai sumber asam amino lisin.

\section{KESIMPULAN DAN SARAN}

\section{Kesimpulan}

1. Untuk pembuatan produk camilan ikan kering renyah dari ikan selar kuning, perendaman garam sebaiknya dilakukan dalam larutan garam konsentrasi 3\% dengan lama perendaman 15 menit.

2. Produk camilan ikan kering yang diolah tanpa dipres dan dikeringkan dengan pengering mekanis lebih dapat diterima secara organoleptis dibandingkan perlakuan lainnya.

\section{Saran}

1. Pengering mekanis dapat digunakan sebagai pengering alternatif bagi penjemuran, terutama pada saat musim hujan. Tetapi untuk penerapannya harus dikaji kelayakannya secara ekonomi.

2. Perlu dilakukan penelitian untuk mengetahui daya simpan produk ini, karena informasi tersebut sangat diperlukan dalam menentukan sistem pemasaran dan jangkauan distribusinya. 


\section{DAFTAR PUSTAKA}

Anonimous. 1987. Liquid Chromatographic Analysis of Amino Acids in Feeds and Foods using a Modification of Pico-Tag Method (Revision). Milipore Corporation. $10 \mathrm{pp}$.

AOAC, 1984. Official Methods of the Association of Official Analytical Chemists $14^{\text {th }}$, AOAC, Virginia. $1141 \mathrm{p}$.

Clucas, I.J. and Ward, A.R. 1996. Post-harvest Fisheries Development: a Guide to Handling, Preservation, Processing and Quality. Natural Resources Institute. Kent. $443 \mathrm{p}$.

Direktorat Jenderal Perikanan. 1998. Statistik Perikanan Indonesia. Dit.Jen Perikanan-DEPTAN. Jakarta 75 p.

Hutuely, L., Bustaman, S. dan Chasanah, E. 1991. Pengaruh konsentrasi garam dan lama penggaraman terhadap mutu ikan layang (Decapterus macrosoma). J.Pen. Pasca Panen Perik. 69:1-15

Khayat, A. and Schwall, D. 1983. Lipid oxidation in sea food. Food Tech. 37(6):130-139.

Nambuary, D.D. 1980. Lipid oxidation in fatty acid. The effect of salt content in meat. J. Food. Sci and Res. 17:176-178.
Noguchi, E. 1972. Salted and dried marine products dalam Okada et al. (Eds.) Utilization of Marine Products. Tokai Regional Fisheries Research Laboratory. Tokyo. p:57-72.

Poernomo, A. 1986a. Salting and Drying Behaviour of Sardines. Master Thesis. UNSW. Australia. 80 p.

Poernomo, A. 1986b. Drying behaviour of salted sardines: II. Effect of temperature and its corresponding relative humidity. J. Pen. Pasca Panen Perik. 54:47-53.

Priono, B. 1984. Studi perbandingan pengeringan ikan asin dengan pengering mekanis, pengering surya dan para-para. J. Pen. Tek. Perik. 32:1-6.

Shimizu, Y. 1997. Traditional Japanese products made from miscellaneous small fish. Paper dipresentasikan pada Final Seminar STD-3 Project: Improved Utilization of Low Value Fish Species. Iloilo City, Filipina, 23-27 September 1997. 7 p.

Zaitzev, V.I., Kizevetter, I., Lagunov, L., Marakova, T., Minder, L. and Podsevalov, Y. 1969. Fish Curing and Processing. MIR Pub., Moscow. $722 \mathrm{p}$ 
Lampiran 1. Penurunan bobot camilan ikan kering selama pengeringan (\%)

Appendix 1. Weight reduction of dried fish snack during drying (\%)

\begin{tabular}{|c|c|c|c|c|c|c|c|c|}
\hline \multirow{2}{*}{$\begin{array}{l}\text { Pengeringan } \\
\text { Drying }\end{array}$} & \multirow{2}{*}{$\begin{array}{l}\text { Lama pengeringan } \\
\text { sebelum } \\
\text { pengepresan (jam) } \\
\text { Drying period before } \\
\text { pressing }\end{array}$} & \multicolumn{7}{|c|}{ Lama pengeringan (jam) (Drying period (hours)) } \\
\hline & & 0 & 3 & 6 & 9 & 12 & 15 & 18 \\
\hline \multirow{5}{*}{$\begin{array}{l}\text { Matahari } \\
\text { Sun drying }\end{array}$} & 3 & 100 & 73.0 & 48.2 & 47.6 & 45.9 & 44.5 & 44.3 \\
\hline & 6 & 100 & 74.7 & 60.4 & 52.3 & 47.6 & 46.8 & 45.8 \\
\hline & 9 & 100 & 73.6 & 59.5 & 57.4 & 48.6 & 47.6 & 46.2 \\
\hline & 12 & 100 & 76.9 & 60.9 & 56.1 & 49.7 & 48.4 & 47.0 \\
\hline & $\begin{array}{l}\text { Tanpa pengepresan } \\
\text { Without pressing }\end{array}$ & 100 & 74.1 & 57.8 & 53.2 & 48.7 & 47.3 & 46.3 \\
\hline \multirow{5}{*}{$\begin{array}{l}\text { Pengering } \\
\text { mekanis } \\
\text { Mechanical } \\
\text { dryer }\end{array}$} & 3 & 100 & 63.8 & 54.8 & 47.3 & 45.8 & 45.2 & \\
\hline & 6 & 100 & 62.6 & 55.7 & 49.9 & 48.9 & 47.7 & \\
\hline & 9 & 100 & 65.8 & 53.1 & 51.5 & 50.3 & 49.2 & \\
\hline & 12 & 100 & 62.9 & 57.0 & 51.0 & 49.3 & 49.2 & \\
\hline & $\begin{array}{c}\text { Tanpa pengepresan } \\
\text { Without pressing }\end{array}$ & 100 & 63.8 & 54.2 & 50.6 & 49.9 & 48.8 & \\
\hline
\end{tabular}

